\title{
The origin of channels on lower Taylor Glacier, McMurdo Dry Valleys, Antarctica, and their implication for water runoff
}

\author{
Robin R. JOHNSTON, Andrew G. FOUNTAIN, Thomas H. NYLEN \\ Department of Geology, Portland State University, Portland, OR 97207-0751, USA \\ E-mail: robj@pdx.edu
}

\begin{abstract}
Well-developed surface channels on Taylor Glacier, McMurdo Dry Valleys, Antarctica, begin as medial moraines incised as shallow, narrow surface depressions, and retain this geometry for tens of $\mathbf{k m}$. Over a distance of $1100 \mathrm{~m}$, the channel geometry dramatically changes, reaching depths $>20 \mathrm{~m}$ and widths $>100 \mathrm{~m}$. After rapidly enlarging, the channels appear to evolve toward a new equilibrium geometry. Compared to the glacier surface, the air temperature in the channels is warmer by $\sim 1.7^{\circ} \mathrm{C}$, wind speed is reduced by $\sim 2.4 \mathrm{~m} \mathrm{~s}^{-1}$ and net shortwave radiation is greater by $\sim 14 \mathrm{~W} \mathrm{~m}^{-2}$. The microclimate in the channel shifts the energy balance towards enhanced melt. Field evidence and energy-balance modeling indicate ablation in the deep channels is $\sim 4.5$ times greater than the local horizontal glacier surface and that melt accounts for $\sim 99 \%$ of the summer ablation, compared to $\sim 75 \%$ on the adjacent horizontal glacier surface. Melt in these channels supplies $65 \%$ of the unaccounted water discharge into the neighboring lake. In large part, the channels generate the water they carry, rather than merely route water generated elsewhere.
\end{abstract}

\section{INTRODUCTION}

The melting of glaciers is a subject important to alpine hydrology (Fountain and Walder, 1998), regional water supplies (Röthlisberger and Lang, 1987) and global sea-level change (Meier, 1984). The specific conditions controlling melt and water runoff depend on local variations in the surface energy balance and the processes conveying the water through the glacier. Few studies have examined the processes controlling meltwater production on polar glaciers. Our study area is the McMurdo Dry Valleys (MDV), Antarctica (Fig. 1), where an intact terrestrial ecosystem thrives in an environment composed of soils, streams and lakes, and is maintained by meltwater generated on the surrounding polar glaciers (Priscu, 1999). To understand the response of this ecosystem requires us to understand the controls on meltwater production. Taylor Glacier is an important source of meltwater for the adjacent Lake Bonney. Because of the large expanse of Taylor Glacier, it potentially can generate a huge water flux to the lake. However, little meltwater is observed on the glacier surface, despite the large surficial channels that characterize the lower part of the glacier (Fig. 2). In this paper, we examine the development of these deeply incised channels, and argue that the channels do not reflect past times of large water flux but instead themselves create the conditions for meltwater generation. Knowledge about channel formation is important to understanding water flow from this glacier and other similar polar glaciers.

Taylor Glacier is an outlet glacier of the East Antarctic ice sheet and fills the western end of Taylor Valley, one of the MDV. Taylor Valley is a northeast-southwest-trending valley $\sim 35 \mathrm{~km}$ long (Fig. 1) and comprises exposed bedrock, sandy-gravelly soil, ice-covered lakes, and ephemeral streams that flow for up to 10 weeks each summer (Conovitz and others, 1998). The streams originate from polar alpine glaciers, which flow from the mountains that border Taylor Valley. The climate in Taylor Valley is that of a polar desert: cold, windy and dry. The mean annual air temperature and wind speed are $-17.8^{\circ} \mathrm{C}$ and $3.4 \mathrm{~m} \mathrm{~s}^{-1}$, respectively, and the mean annual relative humidity is $64 \%$ (Doran and others, 2002; Nylen and others, 2004). The average annual precipitation at the valley bottom, occurring as snow, is $<10$ cm w.e. (Keys, 1980; Bromley, 1985).

Mass-balance studies indicate that glacier accumulation zones in the MDV gain about $10-30 \mathrm{~cm}$ of snow, and ablation zones lose about $6-15 \mathrm{~cm}$ of ice, annually (Fountain and others, 1998). In the lowermost part of the glaciers, sublimation accounts for $40-80 \%$ of the total ablation, melt for $20-60 \%$ and calving $<5 \%$ (Fountain and others, 1998; Lewis and others, 1998). The glacier termini often form cliffs $\sim 20 \mathrm{~m}$ high. Ablation on the vertical cliffs is much higher than elsewhere on the glaciers. On Canada Glacier in Taylor Valley the non-calving ablation was 3-6 times greater than on the horizontal surface (Lewis and others, 1998). Wind speeds along the cliff faces were nearly half those recorded on the glacier surface, and net radiation was greater. Together these factors favor melt over sublimation, a more efficient ablative process than melt. Chinn

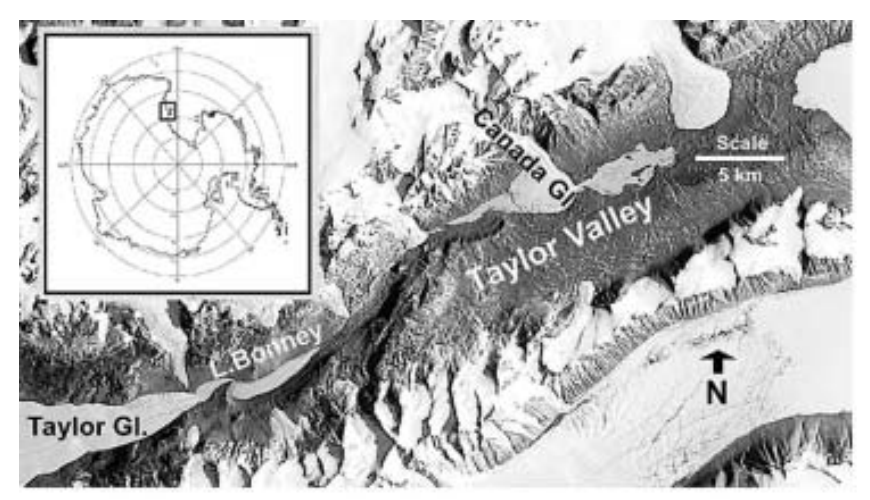

Fig. 1. Taylor Valley in the McMurdo Dry Valleys. Inset (boxed) is its location in Antarctica. 

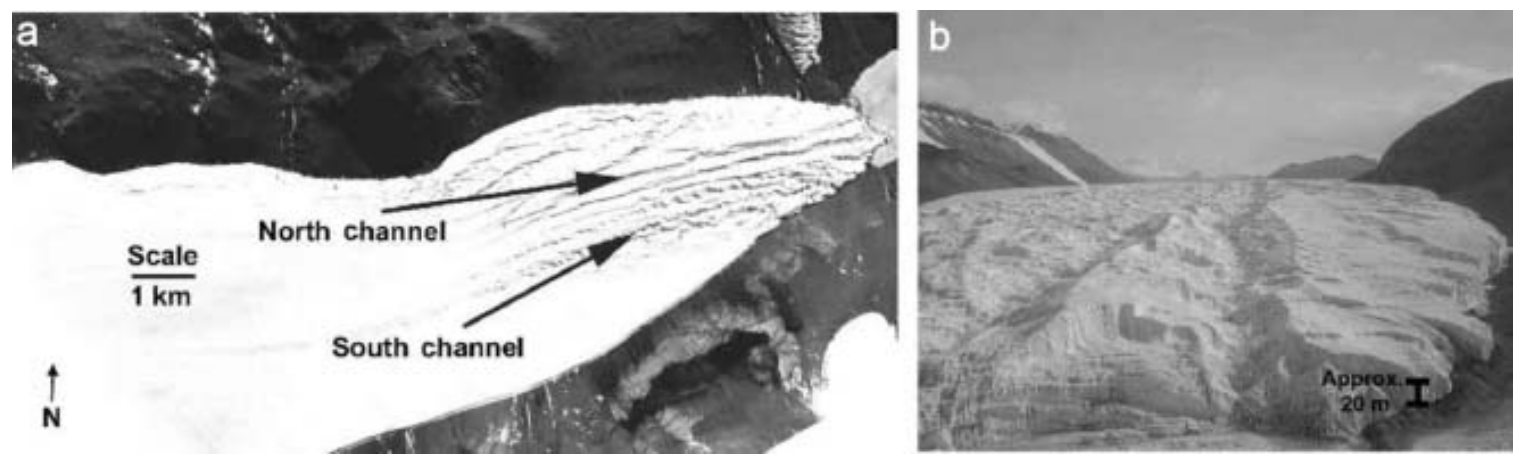

Fig. 2. (a) Aerial photograph of Taylor Glacier showing the locations of the north and south channels (McMurdo Dry Valleys Long-Term Ecological Research, http://huey.colorado.edu/LTER/). (b) Aerial view looking up-glacier at the channels on Taylor Glacier. The vertical terminus cliff in the foreground is $\sim 20 \mathrm{~m}$ high.

(1987) found similar results for vertical ice faces away from the terminus on Wright Lower Glacier in Wright Valley.

Satellite images and vertical aerial photography show that the channels originate from medial moraines whose path can be traced tens of $\mathrm{km}$ up-glacier from the terminus. Our work focuses on two of these channels within $\sim 10 \mathrm{~km}$ of the terminus. The fieldwork consisted of measuring the geometry of the channels and the meteorological environment within the channel and on the adjacent glacier surface. From the meteorological measurements, the energy balance is calculated within and outside of the channels to estimate meltwater flux and to understand the development of the channels.

\section{FIELD METHODS}

Fieldwork was conducted over two summer seasons (1999/2000 and 2000/01) on two channels, identified as the north and south channels (Fig. 2). To characterize the channel geometry, cross-sections were surveyed (global positioning system and optical surveys) on both channels, 15 on the north channel and 13 on the south channel, at roughly $0.5 \mathrm{~km}$ intervals. A longitudinal profile of both the channel bottom and surface adjacent to the channel was measured on the north channel. All survey errors were $<4.5 \mathrm{~cm}$. Surface albedo was measured at each surveyed point. The cross-section survey of the north channel began roughly $4 \mathrm{~km}$ down-glacier from the start of the south channel survey. All down-glacier distances reported in the paper are with respect to ablation stake 90 (Fig. 3).

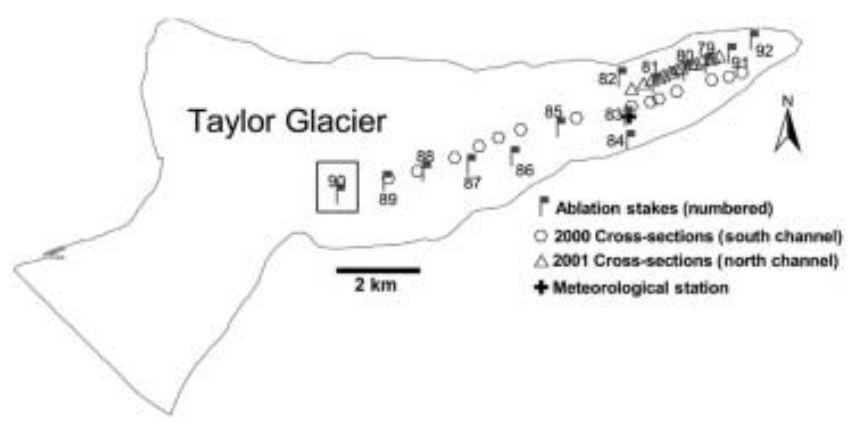

Fig. 3. Location of ablation stakes (flags), cross-sections (hexagons and triangles) and the meteorological station (the cross located at stake 83) on Taylor Glacier. Stake 90 (boxed) is the datum for all distances down-glacier.
The meteorological station on Taylor Glacier, 'Taylor Station' near ablation stake 83, is our reference station and has recorded the standard variables (air and ice temperature $\left( \pm 0.02^{\circ} \mathrm{C}\right)$, relative humidity $(<1 \%)$, incoming and outgoing shortwave radiation $( \pm 3 \%)$, wind speed $\left( \pm 0.3 \mathrm{~ms}^{-1}\right)$ and wind direction $\left( \pm 3^{\circ}\right)$ ) since the $1994 / 95$ season. To define the local lapse rate, temperature loggers were installed during the 1999/2000 field season. Five Onset StowAway XTI temperature loggers (Onset Computer Corp.) were mounted $1 \mathrm{~m}$ above the ice surface on bamboo poles near ablation stakes, and temperatures were recorded hourly. A temporary meteorological station was established in the north channel, about $3 \mathrm{~km}$ down-glacier from Taylor Station and $193 \mathrm{~m}$ lower in elevation, from 22 November 2000 to 5 January 2001. A pair of temporary meteorological stations within the channel and at the channel periphery were deployed from 6 to 15 January 2001, and were located about $2 \mathrm{~km}$ down-glacier from Taylor Station. All the temporary stations recorded air temperature, wind speed and direction, incoming and outgoing shortwave radiation, and relative humidity.

\section{CHANNEL GEOMETRY RESULTS}

The two channels begin to widen and deepen at about the same location $\sim 7 \mathrm{~km}$ down-glacier from stake 90 . The width of the north channel increases from $10 \mathrm{~m}$ to $110 \mathrm{~m}$ over $2 \mathrm{~km}$, and the width of the south channel (Fig. 4) increases from $10 \mathrm{~m}$ to $120 \mathrm{~m}$ over about $0.5 \mathrm{~km}$. The depth increases from $1 \mathrm{~m}$ to about $24 \mathrm{~m}$ over roughly 1.3 and $2.5 \mathrm{~km}$ for the north and south channels, respectively. For the first $7 \mathrm{~km}$ down-glacier, the ratio of width to depth is relatively constant $(\sim 8)$ for the south channel (Fig. 4) and likely the same for the north channel. From about 7 to $8 \mathrm{~km}$ down-glacier, a region of transition ensues and the widthto-depth ratio increases dramatically. This is followed by a second relatively constant width-to-depth ratio (approaching 4) toward the end of the survey. Based on surface velocity measured at the ablation stakes (Fountain, unpublished data), the estimated travel time of the ice along the glacier surface, from stake 90 down-glacier to the survey end ( $\sim 10.5 \mathrm{~km}$ distance and about $3 \mathrm{~km}$ from the glacier terminus), is $\sim 1500$ years for the south channel (Fig. 4). During the region of transition, lasting $\sim 160$ years, channel widening is estimated to peak at about $1.5 \mathrm{~m} \mathrm{a}^{-1}$, while the peak deepening rate is estimated to be about $0.15 \mathrm{~m} \mathrm{a}^{-1}$. 

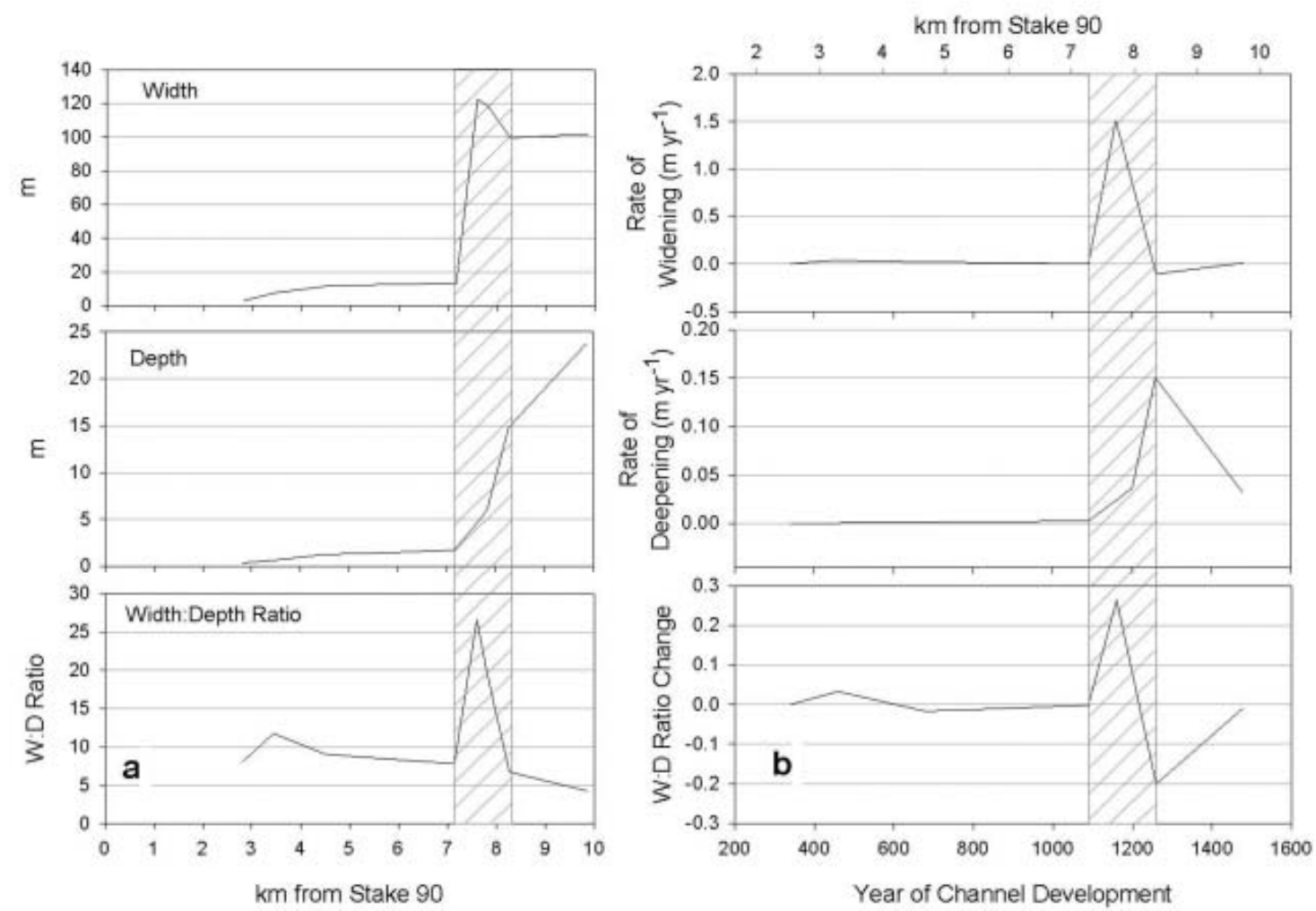

Fig. 4. (a) Width, depth and width-to-depth ratio of south channel with distance down-glacier; and (b) rate of change in width, depth and width-to-depth ratio of south channel. The region of transition is hatched.

The average slopes of the north- and south-facing walls of the north channel are $7^{\circ}$ and $13^{\circ}$ from horizontal, respectively, until $\sim 7.5 \mathrm{~km}$ down-glacier, after which the slopes increase. The slope of the north-facing wall down-glacier increases to $\sim 30^{\circ}$ and that of the south-facing wall to $\sim 25^{\circ}$. However, the north-facing wall is composed of steps with $1-3 \mathrm{~m}$ rises averaging $60^{\circ}$ from horizontal.

\section{METEOROLOGICAL MEASUREMENT RESULTS}

The air temperatures measured on the bamboo stakes were highly correlated with Taylor Station $\left(r^{2} \sim 0.97\right)$. The air cools about $3^{\circ} \mathrm{C}$ over roughly $9.2 \mathrm{~km}$ up-glacier, corresponding to a lapse rate of about $-0.8^{\circ} \mathrm{C}(100 \mathrm{~m})^{-1}$. The air temperature at the location where channel incision begins in earnest is $-4.4^{\circ} \mathrm{C}$. The rate of summer ( $\sim 2$ months) surface ablation also changes, from $-6.2 \mathrm{~cm}$ w.e. up-glacier of this location to $-12.5 \mathrm{~cm}$ w.e. down-glacier.

Comparing results from Taylor Station and the first temporary channel station shows that the average air temperatures were $-4.5^{\circ} \mathrm{C}\left( \pm 0.02^{\circ} \mathrm{C}\right)$ and $-2.8^{\circ} \mathrm{C}$ $\left( \pm 0.02^{\circ} \mathrm{C}\right)$, respectively (Table 1$)$. The average wind speed and relative humidity were reduced in the channel by $1.8 \mathrm{~m} \mathrm{~s}^{-1}(41 \%)$ and $9 \%$, respectively. Net shortwave radiation was greater by $\sim 50 \mathrm{~W} \mathrm{~m}^{-2}(37 \%)$ in the channel. At both stations, wind direction was bimodal in the up- and down-valley directions.

The paired temporary stations showed that air temperature was again warmer in the channel, by about $1.3^{\circ} \mathrm{C}$ $(20 \%)$, and wind speed was reduced by about $3.1 \mathrm{~m} \mathrm{~s}^{-1}$ (88\%). Relative humidity was 5\% greater in the channel, and the net shortwave radiation was greater at the glacier surface
Table 1. Summary of average meteorological variables at the surface and in the channels. $T$ is air temperature, WSp is wind speed, $\mathrm{RH}$ is relative humidity and $\mathrm{SW}_{\text {net }}$ is net shortwave radiation. The time period t 1 is $18-25$ January 1999, t2 is 12 November 2000 to 5 January 2001, and t3 is 6-15 January 2001. Surface is either Taylor Station ( $\mathrm{t} 1$ and $\mathrm{t} 2$ ) or a temporary periphery station ( $\mathrm{t} 3$ ). Channel during t 1 is located $5 \mathrm{~km}$ down-glacier from Taylor Station, during t2 is $3 \mathrm{~km}$ down-glacier from Taylor Station, and during t 3 is $2 \mathrm{~km}$ down-glacier from Taylor Station (t3), running simultaneously with the periphery station at $\mathrm{t} 3$. Difference is the change from the surface to the channel

\begin{tabular}{|c|c|c|c|c|}
\hline & Time period & Surface & Channel & Difference \\
\hline \multirow{4}{*}{$T\left({ }^{\circ} \mathrm{C}\right)$} & t1 & -1.4 & 0.7 & +2.1 \\
\hline & $\mathrm{t} 2$ & -4.5 & -2.8 & +1.7 \\
\hline & t3 & -6.6 & -5.3 & +1.3 \\
\hline & Average difference & & & +1.7 \\
\hline \multirow{4}{*}{ WSp $\left(\mathrm{m} \mathrm{s}^{-1}\right)$} & $\mathrm{t} 1$ & 3.5 & 1.2 & -2.3 \\
\hline & $\mathrm{t} 2$ & 4.4 & 2.6 & -1.8 \\
\hline & $\mathrm{t} 3$ & 3.5 & 0.4 & -3.1 \\
\hline & Average difference & & & -2.4 \\
\hline \multirow{4}{*}{$\mathrm{RH}(\%)$} & $\mathrm{t} 1$ & 63 & 58 & -5 \\
\hline & $\mathrm{t} 2$ & 62 & 53 & -9 \\
\hline & $\mathrm{t} 3$ & 65 & 70 & +5 \\
\hline & Average difference & & & -3 \\
\hline \multirow{4}{*}{$S W_{\text {net }}\left(\mathrm{Wm}^{-2}\right)$} & $\mathrm{t} 1$ & 120 & 143 & +23 \\
\hline & $\mathrm{t} 2$ & 128 & 176 & +48 \\
\hline & t3 & 109 & 80 & -29 \\
\hline & Average difference & & & +14 \\
\hline
\end{tabular}

Note: Lapse rate ranges from -0.7 to $-1.0^{\circ} \mathrm{C}(100 \mathrm{~m})^{-1}$. Average is $-0.8^{\circ} \mathrm{C}$ $(100 \mathrm{~m})^{-1}$ and is consistent over the two field seasons studied. 


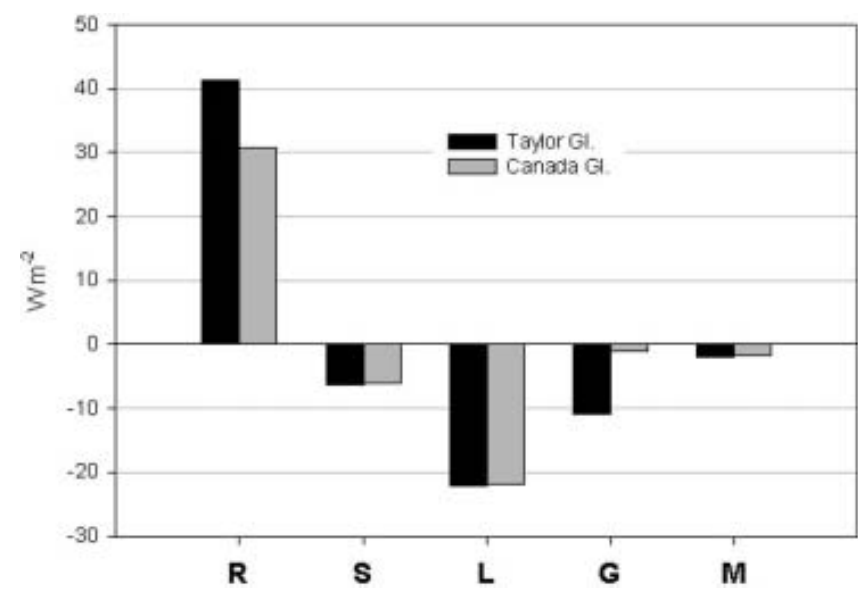

Fig. 5. Energy-balance fluctuations within the channel and at the periphery for Taylor and Canada Glaciers, summer 2000/01. $R$ is net radiation, $S$ is sensible heat, $L$ is latent heat, $G$ is ice heat flux and $M$ is melt energy calculated as a residual.

by an average $29 \mathrm{Wm}^{-2}(27 \%)$. Meteorological data collected in a channel near the terminus of Taylor Glacier from 18 to 25 January 1999 are also presented as supplementary data in Table 1 (personal communication from K. Lewis, 2001). Overall, a microclimate develops in the channels different from the glacier surface: on average, the channels are warmer by about $1.7^{\circ} \mathrm{C}$, wind speed is reduced by about $2.4 \mathrm{~m} \mathrm{~s}^{-1}$, relative humidity is about the same, and net shortwave radiation is greater by about $14 \mathrm{~W} \mathrm{~m}^{-2}$.

\section{ENERGY-BALANCE MODEL}

We developed an energy-balance model to estimate the melt rate on the glacier surface and within the channels to determine the relative importance of the broad horizontal surfaces and the channels in meltwater generation. The model is one-dimensional and is based on Paterson's (1994) summary,

$$
R+S+L+G+P+M=0,
$$

where $R$ is net radiation flux, $S$ is sensible-heat flux, $L$ is latent-heat flux, $G$ is flux of heat through the ice column, $P$ is energy flux supplied through precipitation, and $M$ is energy of fusion (calculated as a residual). $P$ is neglected because of the low rate of precipitation in the dry valleys, and its temperature is probably close to the ice surface temperature. All the terms in Equation (1) are in units of $\mathrm{W} \mathrm{m}^{-2}$, and the sign convention is positive for energy fluxes toward the glacier-air interface and negative for fluxes away from the interface. See the Appendix for details of the model and associated errors.

The average daily values for sensible heat, $S$, and latent heat, $L$, for summer $1994 / 95$ at Taylor Station are similar to those reported by Lewis (1996) at Canada Glacier. Average net radiation, $R$, was greater at Taylor Glacier by $\sim 11 \mathrm{~W} \mathrm{~m}^{-2}$, which is consistent with a higher overall solar flux in the upper reaches of Taylor Valley (Dana and others, 1998). Ice heat flux, $G$, at Taylor was greater than on Canada Glacier, presumably because calculations on Taylor Glacier were based on estimated ice temperatures that resulted in a constant temperature difference between $0.2 \mathrm{~m}$ (surface) and $1 \mathrm{~m}$ depths and/or because of radiative heating of the thermistors on Canada Glacier. Comparison of the model results of estimated ablation (latent heat and melt) over the season ( $\sim 65$ days) at Taylor Station with measured ablation at the nearby ablation stake was good, -7.8 and $-7.0 \mathrm{~cm}$, respectively. Of the estimated ablation, sublimation accounted for $-4.4 \mathrm{~cm}$ w.e. ( $56 \%$ ) and $-3.4 \mathrm{~cm}$ w.e. $(44 \%)$ of melt.

Results from the 2000/01 season, when temporary stations were placed within the channel and at the channel periphery, showed that net radiation was higher within the channel than on the periphery and both sensible- and latentheat fluxes were much lower, as expected with the reduced wind speed (Fig. 5). Ice heat fluxes are similar at the two locations. These conditions result in modeled melt energy about eight times greater in the channel due to the reduced sublimation. The measured ablation at the stake closest to the temporary stations was $-11.2 \mathrm{~cm}$ w.e. over a 65 day period. The modeled ablation at the channel periphery is $-10.9 \mathrm{~cm}$ w.e., of which $-2.7 \mathrm{~cm}$ w.e. $(25 \%)$ is sublimation and $-8.2 \mathrm{~cm}$ w.e. $(75 \%)$ is melt. Unfortunately, the ablation within the channel was not measured. It was therefore estimated from measurements in the 2001/02 season, which showed that ablation in the channel was 4.5 times the measured surface ablation. Assuming this ratio applies to the 2000/01 season, ablation in the channel was about $-50.4 \mathrm{~cm}$ w.e. The modeled ablation within the channel is about $-55.9 \mathrm{~cm}$ w.e., of which $-0.3 \mathrm{~cm}$ w.e. $(1 \%)$ is due to sublimation and $-55.6 \mathrm{~cm}$ w.e. $(99 \%)$ is due to melt. The error of the modeled ablation can be as high as $17 \mathrm{~cm}$ w.e. over a season, which overwhelms the magnitude of measured ablation on the glacier surface. This large error is a consequence of the error accumulating in the melt term of Equation (1) and its relative size compared to the small magnitude of measured ablation.

\section{MELTWATER CONTRIBUTION TO LAKE BONNEY}

Stream-flow to Lake Bonney is monitored annually at streams that enter the lake. The last complete gauging record for streams entering Lake Bonney is from January 1998 to January 1999. The volume change in Lake Bonney over that period was $6.1 \times 10^{5} \mathrm{~m}^{3}$ and the monitored stream input was $4.6 \times 10^{5} \mathrm{~m}^{3}$ (McMurdo Dry Valleys Long-Term Ecological Research, http://huey.colorado.edu/LTER/). Much of the residual volume change of $1.5 \times 10^{5} \mathrm{~m}^{3}$ must originate from the channels on Taylor Glacier which discharge directly into the lake and are unmeasured. We estimated the stream-flow from these channels using average surface and channel seasonal ablation, survey data to make a roughestimate channel area, and fraction of melt from the energy balance within the channel. The average surface ablation on Taylor Glacier for the summer season 1998/99 was $-9.0 \mathrm{~cm}$ w.e. If we assume that the ratio of channel to surface ablation also applies to the 1998/99 season, and that about $99 \%$ of the ablation is attributable to melt (from energybalance model results in the channel), then the estimated meltwater volume from the channels is $1.0 \times 10^{5} \mathrm{~m}^{3}$, which accounts for two-thirds of the unmeasured runoff. The other third may come from unmeasured melt along the ice cliffs of glaciers between the measured streams.

\section{DISCUSSION AND CONCLUSIONS}

The deeply incised features in the lower ablation zone of Taylor Glacier are not unique in the MDV. However, these 
long parallel channels, traced tens of $\mathrm{km}$, are distinctive and cover $\sim 40 \%$ of the lower ablation zone. As the channels are advected down-glacier they slowly widen $\left(<0.1 \mathrm{~m} \mathrm{a}^{-1}\right)$ and deepen $\left(<0.01 \mathrm{~m} \mathrm{a}^{-1}\right)$, maintaining a width-to-depth ratio of about 8 . The channels rapidly change configuration from shallow, narrow geometry to deep, wide features over about a 160 year period. Peak widening rate is $\sim 1.5 \mathrm{~m} \mathrm{a}^{-1}$ and peak deepening rate is $0.15 \mathrm{~m} \mathrm{a}^{-1}$. After this rapid change in geometry, enlargement slows and approaches a width-todepth ratio of $\sim 4$ near the glacier terminus.

We hypothesize that the dark morainal material melts into the ice, forming the shallow channels observed for many kilometers. As the channel advects down-glacier into a warmer climate, increased ablation deepens the channel below some threshold, a wind shadow is formed against the cool surface winds, and a warmer microclimate develops. The location of rapid channel incision coincides with an increase in surface ablation and local air temperatures (2000/01) of $-4.4^{\circ} \mathrm{C}$. This air temperature may be a threshold in these meteorological conditions for melt to begin to occur. The reduced wind in the channels reduces the turbulent heat losses via sensible and latent processes, and the multiple reflections of the shortwave radiation off the channel walls, as well as solar incident angle, increase ice temperature. Together these effects shift the energy balance from a turbulence-dominated heat loss to a melt-dominated environment. The more energy-efficient mass loss through melt (heat of fusion, $3.3 \times 10^{5} \mathrm{~J} \mathrm{~kg}^{-1}$ ) vs sublimation (heat of vaporization, $2.8 \times 10^{6} \mathrm{~J} \mathrm{~kg}^{-1}$ ) increases channel ablation over the ablation on the nearby glacier surface. Eventually, a steady state evolves between channel width and depth because, as the channels deepen, the bottom is increasingly shaded by the channel walls and the latter must widen before the channel continues to deepen. We believe that the channels developed from differences in energy balance initiated by differences in topography. It could be argued that channels might form by thermal erosion from flowing water. However, that process would form narrow slot canyons rather than the wide channels observed. Additionally, the onset of dramatic channel development occurs just down-glacier from a minor bottlenecking of the glacier and a slight overdeepening indicated by isolated groundpenetrating radar (P. Langevin, unpublished data). Therefore, lateral and longitudinal extension may work together to affect channel dynamics. However, more radar work would need to be done to confirm subglacial conditions.

The solar regime also plays a role in channel morphology. The solar ellipse (the path the sun traces in the Taylor Valley sky) during the melt season ranges between $11^{\circ}$ (southern sky) and $36^{\circ}$ (northern sky) above horizontal. As a result, the north-facing walls receive more intense radiation than the south-facing walls. The north-facing walls are, on average, more steeply inclined than the south-facing walls, and they also have steeply inclined regions whose average slope is $60^{\circ}$, yielding a nearly perpendicular solar incident angle of $84^{\circ}$ when the sun is at its maximum elevation. Therefore, the channels may be equilibrating to the solar regime in the valley.

In summary, although the channels observed on Taylor Glacier drain meltwater from the broad flat surface and route it off the glacier, the channels themselves are important sources of runoff to Lake Bonney, contributing an extra $\sim 20 \%$ to the measured runoff. The channels probably form due to a microclimate that develops in the shallow channels when they deepen sufficiently. The microclimate, unlike the climate on the broad glacier surface, favors melt over sublimation. This more effective ablative process within the channels results in a dramatic and rapid change in channel geometry. Whether the channels could eventually grow large enough to lose their distinctive microclimate and terminate growth is uncertain since they are advected to the glacier terminus before that eventuality.

\section{ACKNOWLEDGEMENTS}

Our work was supported by US National Science Foundation, Office of Polar Programs grant NSF OPP-9813061. Discussions with K. Lewis were valuable. We received great support from Raytheon Polar Services and in particular from J. Scanniello. We appreciate the support of, and discussions with, our colleagues on the McMurdo Dry Valleys LongTerm Ecological Research project. In addition, we are especially grateful for the thoughtful feedback from peer reviewers of this paper.

\section{REFERENCES}

Arya, S.P.S. 2001. Introduction to micrometeorology. San Diego, CA, Academic Press.

Baird, D.C. 1962. Experimentation: an introduction to measurement theory and experiment design. Englewood Cliffs, NJ, Prentice-Hall.

Bromley, A.M. 1985. Weather observations in Wright Valley, Antarctica. Wellington, New Zealand Meteorological Service. (Information Publication 11.)

Chinn, T.J.H. 1987. Accelerated ablation at a glacier ice-cliff margin, Dry Valleys, Antarctica. Arct. Alp. Res., 19(1), 71-80.

Conovitz, P.A., D.M. McKnight, L.H. MacDonald, A.G. Fountain and H.R. House. 1998. Hydrologic processes influencing streamflow variation in Fryxwell Basin, Antarctica. In Priscu, J.C., ed. Ecosystem dynamics in a polar desert: the McMurdo Dry Valleys, Antarctica. Washington, DC, American Geophysical Union.

Dana, G.L., R.A. Wharton, Jr and R. Dubayah. 1998. Solar radiation in the McMurdo Dry Valleys, Antarctica. In Priscu, J.C., ed. Ecosystem dynamics in a polar desert: the McMurdo Dry Valleys, Antarctica. Washington, DC, American Geophysical Union, 39-64.

Doran, P.T. and 6 others. 2002. Valley floor climate observations from the McMurdo dry valleys, Antarctica, 1986-2000. J. Geophys. Res., 107(D24), 4772. (10.1029/2001JD002045.)

Fountain, A.G. and J.S. Walder. 1998. Water flow through temperate glaciers. Rev. Geophys., 36(3), 299-328.

Fountain, A.G., G.L. Dana, K.J. Lewis, B.H. Vaughn and D.M. McKnight. 1998. Glaciers of the McMurdo Dry Valleys, southern Victoria Land, Antarctica. In Priscu, J.C., ed. Ecosystem dynamics in a polar desert: the McMurdo Dry Valleys, Antarctica. Washington, DC, American Geophysical Union, 65-75.

Goff, J.A. and S. Gratch. 1946. Low-pressure properties of water from $-160^{\circ} \mathrm{F}$ to $212^{\circ} \mathrm{F}$. Trans. Am. Soc. Heat. Vent. Eng., 52, 95-121.

Grenfell, T.C. and D.K. Perovich. 1981. Radiation absorption coefficients of polycrystalline ice from $400-1400 \mathrm{~nm}$. J. Geophys. Res., 86(C8), 7447-7450.

Hobbs, P.V. 1974. Ice physics. Oxford, Clarendon Press.

Keys, J.R. 1980. Air temperature, wind, precipitation and atmospheric humidity in the McMurdo region. Wellington, Victoria University of Wellington.

Lewis, K.J. 1996. Surface energy balance and meltwater production for a dry valley glacier, Taylor Valley, Antarctica. (MSc thesis, University of Colorado.) 
Lewis, K.J., A.G. Fountain and G.L. Dana. 1998. Surface energy balance and meltwater production for a Dry Valley glacier, Taylor Valley, Antarctica. Ann. Glaciol., 27, 603-609.

Meier, M.F. 1984. Contribution of small glaciers to global sea level. Science, 226(4681), 1418-1421.

Nylen, T.H., A.G. Fountain and P.T. Doran. 2004. Climatology of katabatic winds in the McMurdo Dry Valleys, southern Victoria Land, Antarctica. J. Geophys. Res., 109(D3), D03114. (10.1029/ 2003JD003937.)

Paterson, W.S.B. 1994. The physics of glaciers. Third edition. Oxford, etc., Elsevier.

Perovich, D.K. 1996. The optical properties of sea ice. CRREL Monogr. 96-1.

Priscu, J. 1999. Life in the valley of the 'dead'. Bioscience, 49, 959. Röthlisberger, H. and H. Lang. 1987. Glacial hydrology. In Gurnell, A.M. and M.J. Clark, eds. Glacio-fluvial sediment transfer: an alpine perspective. Chichester, etc., Wiley, 207-284.

Satterlund, D.R. 1979. An improved equation for estimating longwave radiation from the atmosphere. Water Resour. Res., 15(6), $1649-1650$

\section{APPENDIX \\ ENERGY-BALANCE MODEL}

\section{Radiative flux}

Net radiation at the glacier surface is

$$
R=\mathrm{SW}_{\text {net }}+\mathrm{LW}_{\text {net }},
$$

where $\mathrm{SW}_{\text {net }}$ and $\mathrm{LW}_{\text {net }}$ are net shortwave and longwave radiation, respectively. We formulated the net shortwave radiation calculation to take into account radiation absorbed in the surface layer of ice (Hobbs, 1974):

$$
\mathrm{SW}_{\text {net }}=[(1-\alpha) \mathrm{SW} \downarrow]\left(1-\mathrm{e}^{(-j z)}\right),
$$

where $\alpha$ is surface albedo, SW $\downarrow$ is the incoming radiation flux, $j$ is the absorption coefficient $\left(\mathrm{m}^{-1}\right)$ and $z$ is the depth into the ice. The absorption coefficient used, $j=1.6 \mathrm{~m}^{-1}$, is a value adjusted, within reasonable limits, in calibrating the energy balance. The coefficient is a value that depends on several variables: wavelength, incident angle and ice structure. Hobbs (1974), Grenfell and Perovich (1981) and Perovich (1996) provide comprehensive treatments of this topic, and it is discussed below in the section on energybalance error and sensitivity. The maximum value of $z$ used is $1 \mathrm{~m}$, consistent with Paterson (1994). Because the ice is typically below $0^{\circ} \mathrm{C}$ and translucent, the energy of absorbed radiation is important.

Net longwave radiation ( $\mathrm{LW}_{\text {net }}$ ) is the difference between incoming longwave radiation from the atmosphere and outgoing longwave radiation from the surface $(L W \downarrow$ and $L W \uparrow$ respectively):

$$
\mathrm{LW}_{\text {net }}=\mathrm{LW} \downarrow-\mathrm{LW} \uparrow=\varepsilon_{\mathrm{a}} \sigma T_{\mathrm{a}}^{4}-\varepsilon_{\mathrm{i}} \sigma T_{\mathrm{i}}^{4},
$$

where $\varepsilon_{\mathrm{a}}$ and $\varepsilon_{\mathrm{i}}$ are air and ice emissivity, respectively (dimensionless), $\sigma$ is the Stefan-Boltzmann constant $\left(5.67 \times 10^{-8} \mathrm{~W} \mathrm{~m}^{-2} \mathrm{~K}^{-4}\right)$, and $T_{\mathrm{a}}$ and $T_{\mathrm{i}}$ are air and ice temperature, respectively, in Kelvin (K). Ice emissivity is 0.95, an average for ice (Arya, 2001). We calculated atmospheric emissivity based on an empirically derived formula:

$$
\varepsilon_{\mathrm{a}}=1.08\left[1-\exp \left(-V_{\mathrm{a}}^{\frac{T_{\mathrm{a}}}{2016}}\right)\right]
$$

(Satterlund, 1979), where $V_{a}$ is atmospheric vapor pressure in mbar and $T_{\mathrm{a}}$ is air temperature $(\mathrm{K})$. Atmospheric vapor pressure is

$$
V_{\mathrm{a}}=\left[611.2\left(10^{X_{\mathrm{a}}}\right)\right] \frac{\mathrm{RH}}{100}
$$

(Goff and Gratch, 1946), where

$$
\begin{aligned}
X_{\mathrm{a}}= & {\left[-9.1\left(\frac{T_{\mathrm{o}}}{T_{\mathrm{a}}}-1\right)\right]-\left[3.6 \log _{10}\left(\frac{T_{\mathrm{o}}}{T_{\mathrm{a}}}\right)\right] } \\
& +\left[0.88\left(1-\frac{T_{\mathrm{a}}}{T_{\mathrm{o}}}\right)\right],
\end{aligned}
$$

$\mathrm{RH}$ is relative humidity, and $T_{\mathrm{O}}$ is the triple point of water, 273.16 K at 611.2 Pa.

\section{Turbulent heat fluxes}

Turbulent heat fluxes include sensible and latent heat. Sensible heat, $S$, is the vertical flux of heat through mechanical and natural convection (wind) and a temperature gradient between the ice and the air above it:

$$
S=\left(1.29 \times 10^{-2}\right) A P u\left(T_{\mathrm{a}}-T_{\mathrm{i}}\right),
$$

\begin{tabular}{|c|c|c|c|c|c|c|c|c|c|}
\hline \multirow{3}{*}{$\begin{array}{l}\text { Energy-balance } \\
\text { term }\end{array}$} & \multicolumn{3}{|c|}{ Taylor Station, 1994/95 } & \multicolumn{3}{|c|}{ Periphery, 2000/01 } & \multicolumn{3}{|c|}{ Channel, 2000/01 } \\
\hline & Ave. & Error & $\begin{array}{c}\text { Seasonal } \\
\text { melt } \\
\text { equivalent }\end{array}$ & Ave. & Error & $\begin{array}{c}\text { Seasonal } \\
\text { melt } \\
\text { equivalent }\end{array}$ & Ave. & Error & $\begin{array}{c}\text { Seasonal } \\
\text { melt } \\
\text { equivalen }\end{array}$ \\
\hline & $\mathrm{Wm}^{-2}$ & $\mathrm{~W} \mathrm{~m}^{-2}$ & cm w.e. & $W m^{-2}$ & $W m^{-2}$ & cm w.e. & $W m^{-2}$ & $W m^{-2}$ & cm w.e. \\
\hline $\mathrm{SW}_{\text {net }}$ & 112.6 & \pm 8.5 & \pm 14.3 & 106.4 & \pm 8.0 & \pm 13.5 & 113.3 & \pm 8.6 & \pm 14.4 \\
\hline $\mathrm{LW}_{\text {net }}$ & -71.3 & $\pm \ll 0.1$ & - & -70.6 & $\pm \ll 0.1$ & - & -67.8 & $\pm \ll 0.1$ & - \\
\hline$R$ & 41.3 & \pm 8.5 & \pm 14.3 & 35.8 & \pm 7.4 & \pm 12.4 & 45.5 & \pm 9.39 & \pm 15.8 \\
\hline$S$ & -6.4 & \pm 0.5 & \pm 0.8 & -7.3 & \pm 0.6 & \pm 0.9 & -0.6 & \pm 0.05 & \pm 0.1 \\
\hline$L$ & -22.1 & \pm 1.6 & \pm 2.7 & -13.6 & \pm 1.0 & \pm 1.7 & -1.5 & \pm 0.1 & \pm 0.2 \\
\hline$G$ & -10.8 & \pm 0.1 & \pm 0.2 & -10.1 & \pm 0.1 & \pm 0.2 & -10.3 & \pm 0.1 & \pm 0.2 \\
\hline
\end{tabular}

where $A(=0.001)$ is the transfer coefficient, $P(=9.74 \times$ $\left.10^{4} \mathrm{~Pa}\right)$ is the atmospheric pressure, $u$ is wind speed $\left(\mathrm{m} \mathrm{s}^{-1}\right)$, and $T_{\mathrm{a}}$ and $T_{\mathrm{i}}$ are the air and ice temperatures $(\mathrm{K})$, respectively.

Table 2. Error in the energy-balance modeling expressed as $\mathrm{W} \mathrm{m}^{-2}$ and as seasonal melt equivalent, assuming 65 days in the season. $S W_{\text {net }}$ is net shortwave radiation, $\mathrm{LW}_{\text {net }}$ is net longwave radiation $R$ is net radiation, $S$ is sensible heat, $L$ is latent heat and $G$ is ice heat flux 
The latent-heat term, $L$, represents the vertical transfer of heat through a phase change from solid or liquid to vapor, or the reverse:

$$
L=22.2 A u\left(V_{\mathrm{a}}-V_{\mathrm{i}}\right),
$$

where $V_{\mathrm{a}}$ and $V_{\mathrm{i}}$ are the atmospheric and ice surface vapor pressures $(\mathrm{Pa})$, respectively. $V_{\mathrm{i}}$ is calculated in the same way as $V_{\mathrm{a}}$ (Equation (A5)), except that humidity at the ice surface is assumed to be saturated, and temperature is the ice temperature, $T_{\mathrm{i}}$.

\section{Heat flux through the ice column}

Valid ice temperatures are available only from the 1994/95 season at the established station on Taylor Glacier. We estimate ice temperature during the 2000/01 season by correlating summer air temperatures with ice temperatures for the 1994/95 season at the established station on Taylor Glacier and using the regression equation to estimate ice temperature in the 2000/01 season. Air temperatures at Taylor Station for summer 1994/95 were better correlated with $0.2 \mathrm{~m}$ ice temperatures $\left(r^{2}=0.79\right)$ than $1.0 \mathrm{~m}$ ice temperatures $\left(r^{2}=0.58\right)$. Both correlations are statistically significant at the $95 \%$ confidence level. Predictably, using a linear regression directly correlates ice and air temperatures with no time lag for conduction, resulting in a constant difference in $0.2 \mathrm{~m}$ and $1 \mathrm{~m}$ ice temperatures. However, because our model produces average energy-balance terms, which are then applied to the season as a whole, this method of estimating ice temperature will compensate for the induced errors. Ice temperatures were presumed constant and equal to the average annual air temperature of $-16.6^{\circ} \mathrm{C}$ at $15 \mathrm{~m}$ depth (Paterson, 1994). We use the $0.2 \mathrm{~m}$ ice temperatures as surface temperatures.

The conduction of heat through the ice column is

$$
G=-k \frac{\partial T}{\partial z}
$$

where $k$ is the thermal conductivity $\left(\mathrm{W} \mathrm{m}^{-1} \mathrm{~K}^{-1}\right)$ of ice and $\partial T / \partial z$ is the ice temperature gradient $\left(\mathrm{K} \mathrm{m}^{-1}\right)$. The empirical formula for thermal conductivity of pure ice (Paterson, 1994) is

$$
k=9.828 \mathrm{e}^{\left(-5.7 \times 10^{-3} T_{\mathrm{i}}\right)} .
$$

We calculated $k$ for the first-season Taylor Station data when the ice temperatures were correct, and used it in the model. For the energy balance within the channel, we calculated $k$ using ice temperatures predicted by the regression equation.

\section{Energy-balance error and sensitivity}

In order to estimate error in the energy-balance results, errors associated with the meteorological instrumentation were propagated through the energy-balance equations
Table 3. Sensitivity analysis in the value of the absorption coefficient, $j$, and the effect it has on net shortwave radiation and resulting melt equivalent. Altering $j$ has no affect on sublimation

\begin{tabular}{crc}
\hline$j$, with $z=1 \mathrm{~m}$ & $\mathrm{SW}_{\text {net }}$ & $\begin{array}{c}\text { Resulting seasonal melt } \\
\text { equivalent }\end{array}$ \\
$\mathrm{m}^{-1}$ & $\mathrm{~W} \mathrm{~m}^{-2}$ & $\mathrm{~cm}$ w.e. \\
& & \\
\hline 0.01 & 1.40 & 180.39 \\
0.1 & 13.43 & 160.48 \\
1 & 89.20 & 35.04 \\
1.5 & 109.62 & 1.59 \\
1.75 & 116.59 & -9.94 \\
3 & 134.08 & -38.90 \\
10 & 141.10 & -50.90 \\
\hline
\end{tabular}

using the general law of error propagation (Baird, 1962),

$$
\sigma_{y}=\sqrt{\sum\left(\frac{\partial y}{\partial x_{i}}\right)^{2} \sigma_{x i}^{2}}
$$

where $\sigma_{y}$ is the error associated with the equation $(y), \partial y / \partial x_{i}$ is the change in equation $y$ with respect to each variable $x_{i}$ $i=1: n$, where $n$ is the number of variables in the equation, and $\sigma_{x i}$ is the standard deviation associated with each variable.

The very low error for net longwave radiation (Table 2) results from a $\pm 0.02^{\circ} \mathrm{C}$ error in temperature (Doran and others, 2002). The error in the net radiation term is dominated by error in the shortwave radiation and generates an error of $\pm 12-15 \mathrm{~cm}$ w.e. in melt calculated over the season. It is important to keep in mind that just $1 \mathrm{~W} \mathrm{~m}^{-2}$ of energy produces $0.20 \mathrm{~cm}$ w.e. sublimation or $1.68 \mathrm{~cm}$ w.e. of melt over a summer season. A simple example of this sensitivity as it applies to the energy balance follows: The error associated with incoming shortwave radiation instrumentation is $\pm 3 \%$. The average incoming shortwave radiation for summer 1994/95 was $\sim 349 \mathrm{~W} \mathrm{~m}^{-2}, 3 \%$ of which is $\sim 10 \mathrm{~W} \mathrm{~m}^{-2}$. This error magnitude alone amounts to $\pm 17 \mathrm{~cm}$ w.e. of melt over the season, more than double the measured ablation.

We arrived at a value of $1.6 \mathrm{~m}^{-1}$ for $j$ by tuning it so that the calculated total ablation was approximately equal to the measured ablation of $-7.0 \mathrm{~cm}$ w.e. over the 1994/95 season. The effect that altering $j$ has on the net shortwave radiation at the glacier surface is illustrated in Table 3. For the 1994/95 summer season at Taylor Station, $j$ had to be 1.5-2 to produce melt. The modeled seasonal melt for the 2000/01 season results from $j$ values of $3.2 \mathrm{~m}^{-1}$ and $1.0 \mathrm{~m}^{-1}$ for the periphery and channel, respectively. These values are the same order of magnitude as the value of $j$ used in calculating the energy balance at Taylor Station during the 1994/95 season. 